\title{
Synthetic studies towards the nor-triterpene pfaffic acid: synthesis of DEF ring fragment via tandem radical cyclization rearrangement reactions ${ }^{1}$
}

\author{
Purakkattle. J. Biju, K. Kaliappan, and G. S. R. Subba Rao* \\ Department of Organic Chemistry, Indian Institute of Science, Bangalore 560 012, India \\ E-mail:gsrsrao@yahoo.com; gsrs@orgchem.iisc.ernet.in
}

Dedicated to Professor P. T. Narasimhan on his $75^{\text {th }}$ birthday

(received 22 Apr 04; accepted 27 Jul 04; published on the web 04 Aug 04)

\begin{abstract}
A tandem 5-exo-trig-vinyl-3-exo-radical cyclization-rearrangement reaction and its allylic radical version was developed (8 and 15 to $\mathbf{9}$ and $\mathbf{1 6}$ respectively) for the synthesis of DEF ring system of the nor-tritepene Pfaffic acid 1.
\end{abstract}

Keywords: Synthesis of a novel tricyclic system, radical cyclisation, nortriterpene

\section{Introduction}

Nishimoto et al isolated ${ }^{2}$ Pfaffic acid, $\mathbf{1}$ a novel hexacyclic nortriterpenoid from the Brazilian plant Pfaffia paniculata kuntze along with its glycoside derivatives called Pfaffosides. In vitro studies demonstrated that pfaffic acid and pfaffosides show high inhibitory effects towards various types of cancer cells such as melanoma B-16, hela S-3 and lewis lung carcinogen cells even at very low concentrations. ${ }^{3}$ Pfaffic acid with its unique structure, having the presence of ten asymmetric centers, coupled with its promising anti-tumor activities prompted us to initiate a program towards its total synthesis. The DEF carbon framework of pfaffic acid incorporates a unique tricyclo[4.4.0. $0^{2,8}$ ]decane 2, a highly intriguing carbocycle. Herein we describe a novel 5exo-trig-vinyl-3-exo-radical cyclization rearrangement reaction and its allyl radical version for the construction of DEF ring system 2 of pfaffic acid from the known ${ }^{4} 1$-methoxy-5methylbicyclo[2.2.2]oct-5-ene-2-one 6 . 


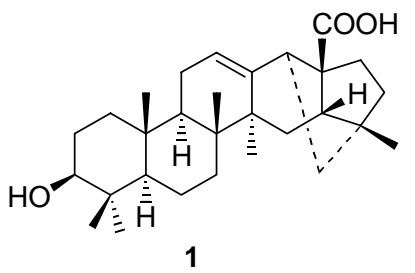

1

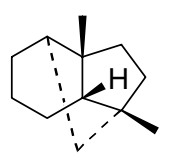

2 : Tricyclo[4.4.0.0 $\left.0^{2,8}\right]$ decane

\section{Results and Discussion}

The bicyclic-ketone 6 was prepared by the cycloaddition of 1-methoxy-3-methylcyclohexa-1,4diene 3 with $\alpha$-chloroacrylonitrile followed by the hydrolysis of the resulting adduct $\mathbf{4}$ according to the method of Monti et al. ${ }^{4}$ However improved and consistent yield of the ketone 6 were obtained by an improved procedure involving the cycloaddition of the diene 3 with acrylonitrile to the adduct $\mathbf{5}$ followed by an oxidative cleavage of the adduct. The alkylation of the lithium enolates generated from bicyclic ketones at low temperature has been reported to yield exclusively the endo alkylated products. ${ }^{5}$ Thus alkylation of the lithium enolate of the known ${ }^{4}$ methoxy ketone 6 with methyl iodide at $-78^{\circ} \mathrm{C}$ gave the ketone 7 , having the methyl group in endo position as evidenced by spectral data. A second alkylation of the lithium enolate generated from the ketone $\mathbf{7}$ at $-78^{\circ} \mathrm{C}$ with propargyl bromide afforded the compound 8 in excellent yield. The acetylenic compound ${ }^{6}$ upon treatment with tributyltinhydride under standard radical cyclization conditions gave a mixture of $\mathbf{9}(58 \%)$ and $\mathbf{1 0}(20 \%)$. The minor product $\mathbf{1 0}$ having the isotwistane carbon framework is obtained through a 5-exo-trig-vinyl radical cyclization. The structure of the major product $\mathbf{9}$ was deduced from its spectral data and confirmed by its conversion to the diketone 11 with $\mathrm{RuCl}_{3} \cdot 3 \mathrm{H}_{2} \mathrm{O} / \mathrm{NaIO}_{4}$. The IR spectrum of $\mathbf{9}$ showed a carbonyl stretching at $1735 \mathrm{~cm}^{-1}$ corresponding to the cyclopentanone carbonyl group while that of compound 10 showed the absorption at $1710 \mathrm{~cm}^{-1}$. The ${ }^{1} \mathrm{HNMR}$ spectrum of $\mathbf{9}$, showed a multiplet at $\delta 3.49$ corresponding to the proton attached to the carbon bearing the methoxyl group while this was absent in $\mathbf{1 0}$.

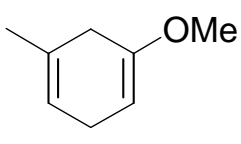

3

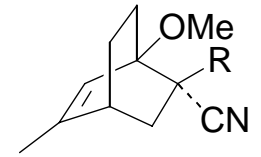

$4, \mathrm{R}=\mathrm{Cl}$

5, $\mathrm{R}=\mathrm{H}$

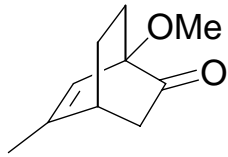

6

In the ${ }^{1} \mathrm{H}$ NMR spectrum of $\mathbf{1 1}$, besides the characteristic multiplet for the proton (CHOMe) at $\delta 3.5$, we observed a singlet at $\delta 3.4$ for the methoxyl protons and two singlets at $\delta 1.1$ and 1.2 corresponding to two tertiary methyl groups. The ${ }^{13} \mathrm{C}$ NMR showed a total 13 carbons, of which the two singlets at $\delta 212.5$ and 214.9 explain the two carbonyl groups and a doublet at $\delta_{\mathrm{C}} 75.4$ shows the presence of the methine carbon, which is attached to the methoxyl group. Further 
structural evidence was obtained from its mass spectral analysis. The mechanism of the reaction involves (Scheme: 2) an initial 5-exo-trig-vinyl radical cyclization resulting in the formation of the isotwistane radical 12, which underwent a further 3-exo-radical cyclization to afford a cyclopropyloxy radical intermediate 13. This cyclopropyloxy radical intermediate 14 rearranged via a homolytic fission of the bond shown in the structure 13, to afford the tricyclo [4.4.0.0 $0^{4,10}$ ]decane derivative 14 .

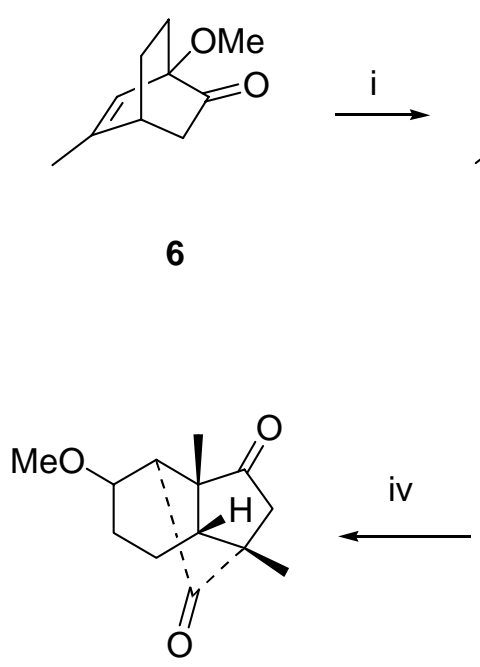

11

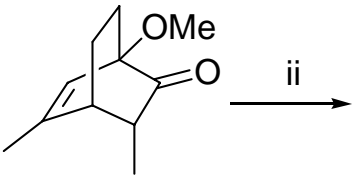

7

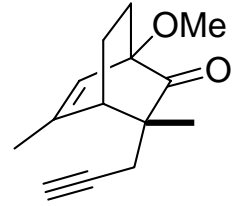

8
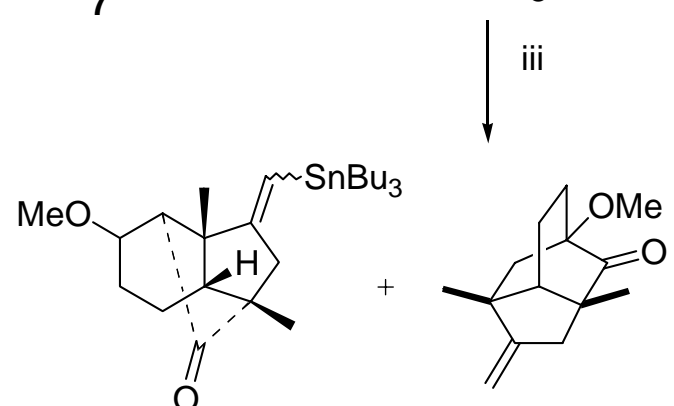

10

Scheme 1. i) LDA, THF, MeI, $-78^{\circ} \mathrm{C}, 87 \%$. ii) LDA, THF, HMPA, Propargyl bromide, $-78^{\circ} \mathrm{C}$, $81 \%$. iii) ${ }^{n} \mathrm{Bu}_{3} \mathrm{SnH}$ (1eq), $\mathrm{AIBN}$ (cat.), $\mathrm{C}_{6} \mathrm{H}_{6}$, reflux, 12 h, 58\%. iv) $\mathrm{RuCl}_{3} \cdot 3 \mathrm{H}_{2} \mathrm{O} / \mathrm{NaIO}_{4}, \mathrm{CCl}_{4}$, $\mathrm{CH}_{3} \mathrm{CN}, \mathrm{H}_{2} \mathrm{O} ; 72 \%$.

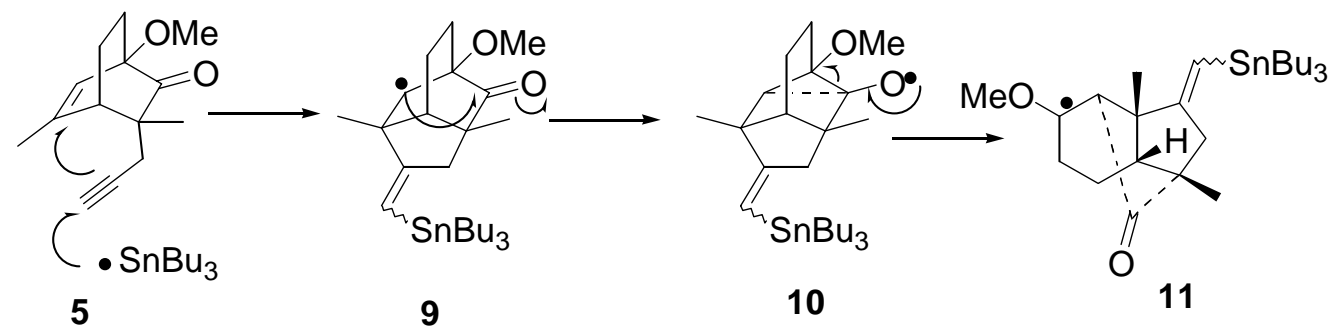

Scheme 2. Mechanism of the tandem reaction.

In an alternative approach, we investigated a similar tandem 5-exo-trig-allyl-3-exo-radical cyclization rearrangement reaction. ${ }^{7}$ The regio and stereo selective alkylation of the ketone 7 , using LDA in THF with 1,4-dibromo-2-methylbut-2-ene at $-78^{\circ} \mathrm{C}$ gave the bromide 15. Treatment of the allylic bromide 15 with ${ }^{\mathrm{n}} \mathrm{Bu}_{3} \mathrm{SnH}$ under standard reaction conditions ${ }^{8}$ afforded a mixture of the rearranged tricyclic ketone $16(80 \%)$ and the reduced product 17, which were easily separated by column chromatography. The compound $\mathbf{1 6}$ was transformed into the 
tricyclic diketone $\mathbf{1 1}$ through the isomerization of the double bond followed by ozonolytic cleavage of the intermediate 18.

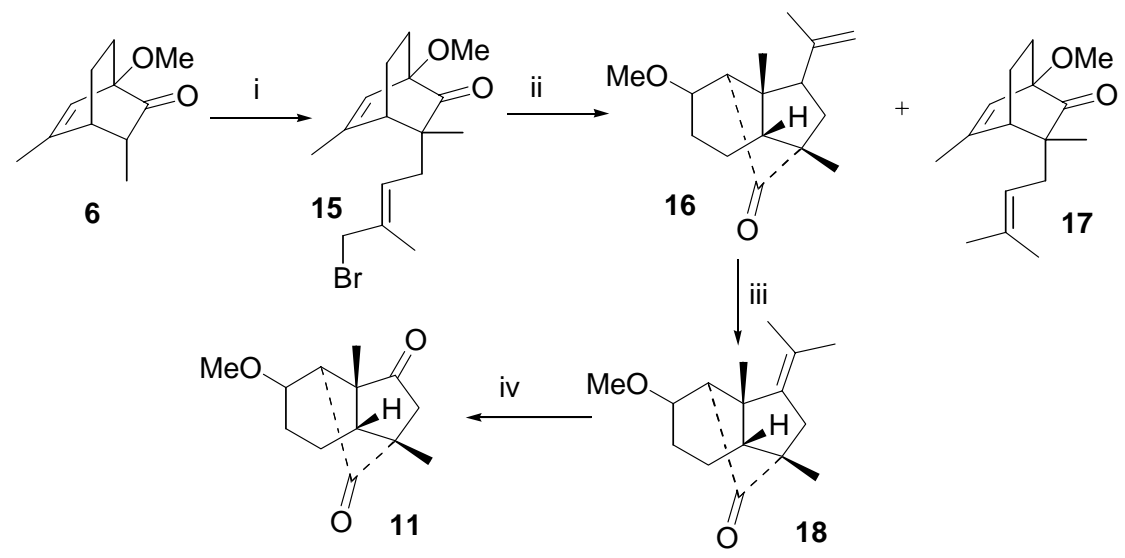

Scheme 3. i) LDA, THF, HMPA, 1,4-dibromo-2-methyl-But-2-ene, $-78^{\circ} \mathrm{C}, \quad 84 \%$. ii) ${ }^{\mathrm{n}} \mathrm{Bu}_{3} \mathrm{SnH}\left(1\right.$ eq), AIBN (cat.) $\mathrm{C}_{6} \mathrm{H}_{6}$, reflux, $12 \mathrm{~h}, 80 \%$. iii) PTSA, toluene, reflux, 95\% iv) $\mathrm{O}_{3}$, $\mathrm{CH}_{2} \mathrm{Cl}_{2},-78^{\circ} \mathrm{C}, \mathrm{Me}_{2} \mathrm{~S}, 93 \%$.

In conclusion, we have accomplished the synthesis of the DEF ring system present in pfaffic acid by using a novel tandem radical cyclisation-rearrangement reaction. The tricyclic diketone is suitably substituted for further elaboration into the desired tetranortriterpene. Further work is in progress.

\section{Experimental Section}

General Procedures. All mps and bps are uncorrected. Mps were recorded on a Mettler FP1 instrument. IR spectra were recorded on Perkin-Elmer 78 and JASCO FT/IR-410 spectrophotometers. NMR spectra were recorded on a JEOL FX-90Q, a Bruker ACF-200, or a JEOL JNM LA-300 spectrometer. The chemical shifts $(\mathrm{ppm})$ and coupling constants $(\mathrm{J} / \mathrm{Hz})$ are reported for standard tetramethylsilane (for ${ }^{1} \mathrm{H}$ ) or the central line of $\mathrm{CDCl}_{3}$ (for ${ }^{13} \mathrm{C}$ ). Mass spectra were recorded on a JEOL MS-DX 303 with inbuilt direct-inlet system, and relative intensities of the ions are given in parentheses. Microanalysis was carried out using a Carlo Erba 1106 instrument. Analytical and preparative TLC was performed on glass plates coated with Acme silica gel $\mathrm{G}$ containing 13\% calcium sulfate as binder. Visualization of the spot was accomplished by exposure to iodine vapour. Acme silica gel (60-120 mesh) was used for column chromatography. Hexane refers to petroleum spirit fraction boiling at $60-80{ }^{\circ} \mathrm{C}$, and ether refers to diethyl ether. All dry solvents were prepared by standard procedures. Liquid ammonia was distilled over sodamide before use. All reactions involving air- and moisture-sensitive reagents were performed under either a blanket of nitrogen or argon-filled balloons. Wherever it is mentioned, the usual work-up means the reaction mixture was washed successively with water 
and brine, dried over anhydrous $\mathrm{Na}_{2} \mathrm{SO}_{4}$, and concentrated in a rotary evaporator at aspirator pressure for the isolation of the product mixture. Unless otherwise stated, all starting materials were obtained from commercial suppliers and were used without further purification.

1-Methoxy-5-methylcyclohexa-1,4-diene (3). A solution of 3-methylanisole (10g, 0.0816mol) in dry ether $(40 \mathrm{ml})$ was added to distilled dry ammonia $(350 \mathrm{ml})$ while stirring. To this mixture was added, lithium $(2.62 \mathrm{~g}, 0.37 \mathrm{~mol})$ in small pieces followed by absolute ethanol $(27 \mathrm{ml}$, $0.45 \mathrm{~mol}$ ) during a period of one hour. Solid $\mathrm{NH}_{4} \mathrm{Cl}$ was added until the blue colour was discharged. The residue obtained after the evaporation of ammonia was cautiously treated with water and the mixture was extracted with ether $(4 \times 125 \mathrm{ml})$. The organic extract was washed with water, brine and dried over anhydrous $\mathrm{Na}_{2} \mathrm{SO}_{4}$ and the solvent was removed to give the diene $3(9 \mathrm{~g}, 89 \%) ; v_{\max } / \mathrm{cm}^{-1} 2900,1690 \& 1660 \mathrm{~cm}^{-1} ; \delta_{\mathrm{H}} 1.70(3 \mathrm{H}, \mathrm{m}), 2.50-2.90(4 \mathrm{H}, \mathrm{m}$, allylic $\left.\mathrm{CH}_{2}\right), 3.57$ (3H, s, -OMe), 4.62 (1H, br s, $\left.-\mathrm{CH}=\mathrm{C}-\mathrm{OMe}\right), 5.40$ (1H, br s, olefinic).

2-Cyano-1-methoxy- 5-methylbicyclo[2.2.2]oct-5-ene (5). A mixture of the diene 3 (9g, $0.0725 \mathrm{~mol})$, acrylonitrile $(9.5 \mathrm{ml}, 0.144 \mathrm{~mol})$, DCMA (cat.) and hydroquinone (cat.) was placed in a sealed tube and heated to $140^{\circ} \mathrm{C}$ for $16 \mathrm{~h}$. After cooling, the reaction mixture was dissolved in ether and filtered through celite. Distillation gave a $1: 1$ mixture of the nitriles $5(8.9 \mathrm{~g}, 71 \%)$ as a colourless liquid, bp $108-110^{\circ} \mathrm{C}$; $v_{\max }$ (neat) 2960, 2240, $1630 ; \delta_{\mathrm{H}}\left(90 \mathrm{MHz}, \mathrm{CDCl}_{3}\right) 1.30-3.00$ $(8 \mathrm{H}, \mathrm{m}), 1.80 \& 1.84(3 \mathrm{H}$, two doublets, $J 1.5 \mathrm{~Hz}, \mathrm{Me}), 3.40(3 \mathrm{H}, \mathrm{s},-\mathrm{OMe}), 5.90(1 \mathrm{H}$, br s, olefinic); m/z $177\left(\mathrm{M}^{+}, 2.5 \%\right), 124$ (100) and 109 (63); (Found 177.1149; $\mathrm{C}_{11} \mathrm{H}_{15} \mathrm{ON}$ requires 177.1151).

1-Methoxy-5-methylbicyclo[2.2.2]oct-5-ene-2-one (6). The nitrile 5 (15g, 0.084mol) in THF $(80 \mathrm{ml})$ was added drop-wise at $-78^{\circ} \mathrm{C}$ to a solution of lithium diisopropylamide $(0.093 \mathrm{~mol})$ prepared by the drop-wise addition of n-butyllithium $(1.6 \mathrm{M}$ in hexane, $58.25 \mathrm{ml}, 0.0932 \mathrm{~mol})$ to diisopropylamine $(12.2 \mathrm{ml}, 0.093 \mathrm{~mol})$ in $\mathrm{THF}(50 \mathrm{ml})$ at $-78^{\circ} \mathrm{C}$ under $\mathrm{N}_{2}$. After stirring for $1 \mathrm{~h}$, oxygen (dried by passing through a $\mathrm{KOH}$ tower) was bubbled into the lithionitrile solution at $78^{\circ} \mathrm{C}$ for $5 \mathrm{~h}$. The reaction mixture was quenched with $1 \mathrm{M}$ sodium sulfite solution $(11.74 \mathrm{~g}$, $0.093 \mathrm{~mol}$ ) and allowed to stir for $30 \mathrm{~min}$ at $0^{\circ} \mathrm{C}$ and than for $12 \mathrm{~h}$ at $25^{\circ} \mathrm{C}$. The reaction mixture was extracted with ether, and the combined organic extracts were washed with $2 \mathrm{~N} \mathrm{NaOH}$ and saturated brine solution and then dried. The solvent was evaporated and the residue purified by vacuum distillation to yield the ketone $6(9.75 \mathrm{~g}, 69.3 \%)$ as colourless liquid. $v_{\max } / \mathrm{cm}^{-1}$ (neat) 2920 and 1720; $\delta_{\mathrm{H}}\left(200 \mathrm{MHz}, \mathrm{CDCl}_{3}\right) 1.83(3 \mathrm{H}, \mathrm{d}, J 2.35 \mathrm{~Hz}, \mathrm{Me}), 1.40-2.10(4 \mathrm{H}, \mathrm{m}), 2.00(2 \mathrm{H}$, d, J 2.5Hz, - $\left.\underline{\mathrm{H}}_{2}-\mathrm{CO}-\right), 2.67$ (1H, m, bridgehead H), $3.43(3 \mathrm{H}, \mathrm{s},-\mathrm{OMe}), 5.77$ (1H, br s, olefinic); $\mathrm{m} / \mathrm{z} 166\left(\mathrm{M}^{+}, 6 \%\right), 138(38), 124$ (50), 123 (100), 110 (54) and 109 (53).

3-(endo)-5-Dimethyl-1-methoxybicyclo[2.2.2]oct-5-en-2-one (7). To a freshly prepared LDA solution [prepared from 1.6 M solution of $n$-BuLi $(8.28 \mathrm{ml}, 13 \mathrm{mmol})$ and diisopropylamine $(1.73 \mathrm{ml}, 13.25 \mathrm{mmol})$ in $20 \mathrm{ml}$ of THF at $-78{ }^{\circ} \mathrm{C}$ under argon was added a solution of the ketone $6(2 \mathrm{~g}, 12 \mathrm{mmol})$ in $20 \mathrm{ml}$ of THF drop-wise. After stirring of the reaction mixture at $-78^{\circ} \mathrm{C}$ for $1 \mathrm{~h}$, methyl iodide $(2.32 \mathrm{ml}, 36 \mathrm{mmol})$ as a solution in $10 \mathrm{ml}$ of THF was added and the mixture was stirred for $1 \mathrm{~h}$. The reaction mixture was poured into saturated aq. ammonium chloride and 
extracted with ether. The ether layer was washed successively with water, aq. sodium thiosulfate, water and brine, and dried over anhydrous $\mathrm{Na}_{2} \mathrm{SO}_{4}$. Removal of the solvent followed by column chromatography over silica gel [ethylacetate-hexane (1:10)] as eluent afforded the ketone 7 as a colorless oil $(1.89 \mathrm{~g}, 87 \%) ; v_{\max } / \mathrm{cm}^{-1} 2960$ and $1720 \mathrm{~cm}^{-1} ; \delta_{\mathrm{H}}(200 \mathrm{MHz}) 1.05(3 \mathrm{H}, \mathrm{d}, J 7.1 \mathrm{~Hz}$, $\mathrm{Me}), 1.6-1.85(4 \mathrm{H}, \mathrm{m}), 1.87(3 \mathrm{H}, \mathrm{d}, J 1.6 \mathrm{~Hz},=\mathrm{C}-\underline{\mathrm{Me}}), 2.07(1 \mathrm{H}, \mathrm{m},-\mathrm{C} \underline{\mathrm{H}}-\mathrm{CO}), 2.46(1 \mathrm{H}, \mathrm{br} \mathrm{s}$, bridgehead $\mathrm{H}), 3.48(3 \mathrm{H}, \mathrm{s},-\mathrm{OMe})$ and $5.61\left(1 \mathrm{H}, \mathrm{s}\right.$, olefinic); $\delta_{\mathrm{C}}(22.5 \mathrm{MHz}) 15.6,21.3,24.2$, 26.1, 43.1, 43.7, 52.4, 83.6, 119.9, 144.4 and 211.4; $\mathrm{m} / \mathrm{z} 180\left(\mathrm{M}^{+}, 3 \%\right), 152$ (55), 137 (100), 124 (90) and 109 (41) (Found: $\mathrm{M}^{+}, 180.1154 \mathrm{C}_{11} \mathrm{H}_{16} \mathrm{O}_{2}$ requires $M, 180.1152$ ).

3,5-Dimethyl-3(endo)-(prop-3-ynyl)-1-methoxybicyclo [2.2.2]decan-2-one (8). To a freshly prepared LDA solution [prepared from 1.6 M solution of $n$-BuLi $(6.93 \mathrm{ml}, 11.1 \mathrm{mmol})$ and diisopropylamine $(1.5 \mathrm{ml}, 11.1 \mathrm{mmol})$ in $20 \mathrm{ml}$ of THF] at $-78{ }^{\circ} \mathrm{C}$ under argon was added a solution of the ketone $7(1.0 \mathrm{~g}, 5.55 \mathrm{mmol})$ in THF $(15 \mathrm{ml})$ drop-wise. The resultant solution was stirred for $1 \mathrm{~h}$ at $-78{ }^{\circ} \mathrm{C}$ and quenched with propargyl bromide $(1.5 \mathrm{ml} \mathrm{g}, 16.66 \mathrm{mmol})$ followed by the addition of HMPA $(1.3 \mathrm{ml}, 5.55 \mathrm{mmol})$. The reaction mixture was stirred overnight, poured into ice-cold water, and extracted with ether $(4 \times 25 \mathrm{ml})$. The combined organic layer was washed successively with $2 \mathrm{M} \mathrm{HCl}$, water and brine and dried over anhydrous $\mathrm{Na}_{2} \mathrm{SO}_{4}$. Removal of the solvent followed by column chromatography on silica gel [ethyl acetate-hexane $(1: 24)$ ] afforded the ketone $8(0.98 \mathrm{~g}, 81 \%)$ as an amorphous solid; $v_{\max } / \mathrm{cm}^{-1} 3260$ and $1720 ; \delta_{\mathrm{H}}$ $(300 \mathrm{MHz}) 1.20(3 \mathrm{H}, \mathrm{s}, \mathrm{Me}), 1.40-2.20(6 \mathrm{H}, \mathrm{m}), 1.89(3 \mathrm{H}, \mathrm{d}, J 1.5 \mathrm{~Hz},=\mathrm{C}-\mathrm{Me}), 2.41(1 \mathrm{H}, \mathrm{dd}, J$ 3.0 and $16.8 \mathrm{~Hz}$, bridgehead $\mathrm{H}), 2.74(1 \mathrm{H}, \mathrm{d}, J 2.1 \mathrm{~Hz}, \mathrm{C} \equiv \mathrm{C} \underline{\mathrm{H}}), 3.48(3 \mathrm{H}, \mathrm{s},-\mathrm{OMe})$, and $5.92(1 \mathrm{H}$, s, olefinic) $\delta_{\mathrm{C}}(75 \mathrm{MHz}) 20.8,21.0,21.1,26.6,27.7,44.3,45.7,52.8,71.5,80.4,84.1,120.3$, 147.1 and 212.3; m/z $218\left(\mathrm{M}^{+} 11 \%\right), 190$ (19), 175 (17), 151 (59), 124 (100) and 109 (24); (Found: $\mathrm{M}^{+}, 218.1306, \mathrm{C}_{14} \mathrm{H}_{18} \mathrm{O}_{2}$ requires $\mathrm{M}^{+}$, 218.1317); (Found $\mathrm{C}$; 76.38, $\mathrm{H} ; 8.46, \mathrm{C}_{14} \mathrm{H}_{18} \mathrm{O}_{2}$ requires $\mathrm{C} ; 76.63, \mathrm{H} ; 8.31 \%$ ).

1,8-Dimethyl-10-tributylstannylmethylene-5-methoxytricyclo[4.4.0.0 $\left.{ }^{2,8}\right]$ decan-7-one (9). To a solution of acetylenic ketone $8(1.0 \mathrm{~g}, 4.5 \mathrm{mmol})$ in degassed benzene $(250 \mathrm{ml})$ was added dropwise, a solution of tributyltinhydride $(1.35 \mathrm{ml}, 5.04 \mathrm{mmol})$ and azobis-isobutyronitrile $(10 \mathrm{mg})$ in dry benzene using a syringe pump for two hours under nitrogen atmosphere. After refluxing for six hours, the reaction mixture was concentrated in vacuo and the residue was taken up in ether, washed with water, brine and dried over anhydrous $\mathrm{Na}_{2} \mathrm{SO}_{4}$. Removal of the solvent followed by column chromatography over silica gel (ethyl acetate-hexane [1:10]) afforded the tricyclic ketone $9(1.2 \mathrm{~g}, 58 \%)$ as colorless oil. $v_{\max } / \mathrm{cm}^{-1} 2940,1735$ and $1610 ; \delta_{\mathrm{H}}(200 \mathrm{MHz}) 0.86(15 \mathrm{H}$, m), $1.13(3 \mathrm{H}, \mathrm{s}, \mathrm{Me}), 1.21(3 \mathrm{H}, \mathrm{s}, \mathrm{Me}), 1.25-2.50(20 \mathrm{H}, \mathrm{m}), 3.33(3 \mathrm{H}, \mathrm{s},-\mathrm{OMe}), 3.49(1 \mathrm{H}, \mathrm{m})$ and $5.72\left(1 \mathrm{H}, \mathrm{t}, J 3.6 \mathrm{~Hz}\right.$ olefinic) $\mathrm{m} / \mathrm{z} 510\left(\mathrm{M}^{+1} 6 \%\right), 453$ (100), 397 (25), 339 (30), 291 (26), 235(34), 177 (17), and 121 (28); [Found: $\mathrm{M}^{+}, 453.1809 \mathrm{C}_{22} \mathrm{H}_{37} \mathrm{O}_{2} \mathrm{Sn}$ (M-But) requires 453.1820]. Further elution with ethyl acetate-hexane (1:5) gave the ketone $10(250 \mathrm{mg})$ as an oil; $v_{\max } / \mathrm{cm}^{-1}$ 1720,1650 and $900 ; \delta_{\mathrm{H}}(300 \mathrm{M} \mathrm{Hz}) 1.14(3 \mathrm{H}, \mathrm{s}, \mathrm{Me}), 1.21(3 \mathrm{H} . \mathrm{s}, \mathrm{Me}), 1.25-2.50(9 \mathrm{H}, \mathrm{m}), 3.32$ $(3 \mathrm{H}, \mathrm{s}, \mathrm{OMe}), 4.7(1 \mathrm{H}, \mathrm{t}, \mathrm{J} 2.1)$ and $5.01(1 \mathrm{H}, \mathrm{t}, \mathrm{J} 2.1)$; (Found: C, 76.42, H, 9.14, $\mathrm{C}_{14} \mathrm{H}_{20} \mathrm{O}_{2}$ requires $\mathrm{C}, 76.36$ and $\mathrm{H}, 9.09 \%$ ). 
1,8-Dimethyl-5-methoxytricyclo[4.4.0.0 $\left.{ }^{2,8}\right]$ decan-7,10-dione (11). To a mixture of stannylated derivative $9(0.453 \mathrm{~g}, 1 \mathrm{mmol})$, carbontetrachloride $(2 \mathrm{ml})$, acetonitrile $(2 \mathrm{ml})$, water $(3 \mathrm{ml})$, sodium metaperiodate $(0.873 \mathrm{~g}, 4.1 \mathrm{mmol})$ and ruthenium chloride hydrate $(5 \mathrm{mg})$ was added and the entire mixture was stirred vigorously at room temperature for six hours. It was then diluted with dichloromethane $(50 \mathrm{ml})$ and phases were separated. The organic layer was washed successively with water, brine and dried. Removal of the solvent afforded the crude product, which was then purified by column chromatography (ethylacetate-hexane [3:7]) to afford the dione $11(\mathbf{0 . 1 8 0 g}$, $72 \%)$ as a solid, crystallized from ether-hexane $(1: 3), \mathrm{mp} 98-100^{0} \mathrm{C} ; v_{\max } / \mathrm{cm}^{-1} 2910$ and $1735 ; \delta_{\mathrm{H}}$ $(300 \mathrm{MHz}) 1.22(3 \mathrm{H}, \mathrm{s}, \mathrm{Me}), 1.25(3 \mathrm{H}, \mathrm{s}, \mathrm{Me}), 1.70-2.30(7 \mathrm{H}, \mathrm{m}), 2.35\left(1 \mathrm{H}, \mathrm{br} \mathrm{s}, \mathrm{C}_{6} \mathrm{H}\right), 3.36(3 \mathrm{H}$, s, -OMe) and 3.58-3.64 (1H, m, Cㅍ-Me); $\delta_{\mathrm{C}}(75 \mathrm{MHz}) 10.4,10.7,19.1,25.6,48.0,51.3,51.5$, 55.1, 56.2, 57.2, 75.4, 212.5 and 214.9. m/z $222\left(\mathrm{M}^{+}\right.$19\%), 207 (3), 190 (5), 162 (35), 147 (31), 128 (100), 94 (95) and 71 (71) (Found: $\mathrm{M}^{+}, 222.1250 . \mathrm{C}_{13} \mathrm{H}_{18} \mathrm{O}_{3}$ requires 222.1246).

3-(endo)-(4-Bromo-3-methylbut-2-enyl)-3,5-dimethyl-1-methoxybicyclo[2.2.2]oct-5-en-2 one (15). To a freshly prepared LDA solution [prepared from $1.6 \mathrm{M}$ solution of $n$-BuLi $(6.93 \mathrm{ml}$, $11.1 \mathrm{mmol})$ and diisopropylamine $(1.45 \mathrm{ml}, 11.1 \mathrm{mmol})$ in $20 \mathrm{ml}$ of THF] at $-78{ }^{\circ} \mathrm{C}$ under argon was added a solution of the ketone $7(1.0 \mathrm{~g}, 5.5 \mathrm{mmol})$ in THF $(10 \mathrm{ml})$ drop wise. The resultant solution was stirred for $1 \mathrm{~h}$ at $-78{ }^{\circ} \mathrm{C}$ and quenched with 1,4-dibromo-2-methylbut-2-ene (3.89 g, $16.9 \mathrm{mmol})$ followed by the addition of HMPA $(0.96 \mathrm{ml}, 11.1 \mathrm{mmol})$. The reaction mixture was stirred overnight, poured into ice-cold water, and extracted with ether $(4 \times 25 \mathrm{ml})$. The combined organic layer was washed successively with $2 \mathrm{M} \mathrm{HCl}$, water and brine and dried over anhydrous $\mathrm{Na}_{2} \mathrm{SO}_{4}$. Removal of the solvent followed by column chromatography on silica gel [ethyl acetate-hexane (1:24)] afforded the ketone $15(1.52 \mathrm{~g}, 84 \%)$ as an oil; $v_{\max } / \mathrm{cm}^{-1} 2940$ and 1710; $\delta_{\mathrm{H}}(200 \mathrm{MHz}) 1.06(3 \mathrm{H}, \mathrm{s}, \mathrm{Me}), 1.40-2.10(4 \mathrm{H}, \mathrm{m}), 1.74(3 \mathrm{H}, \mathrm{s}, \mathrm{Me}), 1.87(3 \mathrm{H}, \mathrm{d}, \mathrm{J} 2.0 \mathrm{~Hz}, \mathrm{Me})$, $2.30\left(2 \mathrm{H}, \mathrm{m}\right.$, allylic $\left.\mathrm{CH}_{2}\right), 2.42(1 \mathrm{H}, \mathrm{d}, \mathrm{J} 2.1 \mathrm{~Hz}$, bridgehead), $3.50(3 \mathrm{H}, \mathrm{s},-\mathrm{OMe}), 3.96(2 \mathrm{H}, \mathrm{s},-$ $\left.\mathrm{CH}_{2}-\mathrm{Br}\right), 5.64\left(1 \mathrm{H}, \mathrm{t}, J\right.$ 7.1, olefinic) and $5.76\left(1 \mathrm{H}\right.$, s, olefinic); $\delta_{\mathrm{C}}(22.5 \mathrm{MHz}) 14.5,20.6,20.6$, 26.7, 35.6, 35.8, 40.8, 44.9, 46.4, 52.5, 83.8, 120.1, 125.7, 133.9, 145.6 and 212.7; $\mathrm{m} / \mathrm{z} 329$ $(\mathrm{M}+2,5 \%), 327\left(\mathrm{M}^{+}\right.$5\%), $247(28), 219$ (93), 151 (61), 124 (100) and 109 (35); (Found: $\mathrm{M}^{+}$, 247.1698; $\mathrm{C}_{16} \mathrm{H}_{23} \mathrm{O}_{2}\left(\mathrm{M}^{+}-\mathrm{Br}\right)$ requires 247.1702).

10-Isoprenyl-1, 8-dimethyl-5-methoxytricyclo $\left[4.4 .0 .0^{2,8}\right]$ decan-7-one (16). To a solution of allylic bromide $15(0.326 \mathrm{~g}, 1.0 \mathrm{mmol})$ in degassed benzene $(200 \mathrm{ml})$ was added drop-wise, a solution of tributyltinhydride $(0.268 \mathrm{ml}, 1.0 \mathrm{mmol})$ and azobis-isobutyronitrile $(10 \mathrm{mg})$ in dry benzene using a syringe pump for two hours under nitrogen atmosphere. After refluxing for six hours, the reaction mixture was concentrated in vacuo and the residue was taken up in ether, washed with water, brine and dried over anhydrous $\mathrm{Na}_{2} \mathrm{SO}_{4}$. Removal of the solvent followed by column chromatography over silica gel (ethyl acetate-hexane [1:30]) afforded the tricyclic ketone $16(0.72 \mathrm{~g}, 80 \%)$ as colorless oil, $v_{\max } / \mathrm{cm}^{-1} 2940,1735$ and $1630 ; \delta_{\mathrm{H}}(300 \mathrm{MHz}) 1.04(3 \mathrm{H}$, $\mathrm{s}, \mathrm{Me}), 1.12(3 \mathrm{H}, \mathrm{s}, \mathrm{Me}), 1.74(3 \mathrm{H}, \mathrm{d}, J 1.5 \mathrm{~Hz}, \mathrm{Me}), 1.40-2.00(7 \mathrm{H}, \mathrm{m}), 2.17-2.22(2 \mathrm{H}, \mathrm{m}) 3.35$ $(3 \mathrm{H}, \mathrm{s},-\mathrm{OMe}), 3.56-3.63(1 \mathrm{H}, \mathrm{m},-\mathrm{CH}-\mathrm{OMe}, 4.76(1 \mathrm{H}, \mathrm{br}$ s, olefinic) and $4.87(1 \mathrm{H}, \mathrm{d}, \mathrm{J} 1.5 \mathrm{~Hz}$ olefinic); m/z 248 (M+10\%), 233 (3), 220 (17), 166 (19), 151 (75), 137(82), 124 (100), and 109 (72) (Found: $\mathrm{M}^{+}, 248.1770 \mathrm{C}_{16} \mathrm{H}_{24} \mathrm{O}_{2}$ requires 248.1773). 
1,8-Dimethyl-10-isopropylidene-5-methoxytricyclo $\left[4.4 .0 .0^{2,8}\right]$ decan-7-one (18). A solution of the keto-olefin $16(0.248 \mathrm{~g}, 1.0 \mathrm{mmol})$ and PTSA $(10 \mathrm{mg})$ in dry benzene $(15 \mathrm{ml})$ was refluxed for $1 \mathrm{~h}$. The reaction mixture was cooled, washed successively with saturated aq. $\mathrm{NaHCO}_{3}$ $(10 \mathrm{ml})$ and brine, and dried over anhydrous $\mathrm{Na}_{2} \mathrm{SO}_{4}$. The solvent was evaporated under reduced pressure and the residue was purified on a silica gel column [ethyl acetate-hexane (1:10)] to yield the ketone $18(0.230 \mathrm{~g}, 95 \%)$ as oil. $v_{\max } / \mathrm{cm}^{-1} 2920$ and $1735 ; \delta_{\mathrm{H}}(90 \mathrm{MHz}) 1.10(6 \mathrm{H}, \mathrm{s}$, $\mathrm{Me}), 1.40(3 \mathrm{H}, \mathrm{s}, \mathrm{Me}), 1.52(3 \mathrm{H}, \mathrm{s}, \mathrm{Me}), 1.60-2.20(7 \mathrm{H}, \mathrm{m}), 2.30\left(1 \mathrm{H}, \mathrm{s}, \mathrm{C}_{6} \mathrm{H}\right) 3.30(3 \mathrm{H}, \mathrm{s}$, OMe), 3.30-3.60 (1H, m, -Cㅡ-O-OMe, $4.76(1 \mathrm{H}$, br s, olefinic) and $4.87(1 \mathrm{H}, \mathrm{d}, J 1.5 \mathrm{~Hz}$ olefinic); (Found $\mathrm{C} ; 77.12, \mathrm{H} ; 9.60, \mathrm{C}_{16} \mathrm{H}_{24} \mathrm{O}_{2}$ requires $\mathrm{C}$; 77.37, $\mathrm{H} ; 9.74 \%$ ).

1,8-Dimethyl-5-methoxytricyclo[4.4.0.0 $\left.{ }^{2,8}\right]$ decan-7,10-dione (11). Ozone was bubbled through a cooled $\left(-78^{\circ} \mathrm{C}\right)$ dichloromethane $(10 \mathrm{ml})$ solution of the olefin $18(0.248 \mathrm{~g}, 1.0 \mathrm{mmol})$ until the solution turned blue. Excess of ozone was removed by bubbling Nitrogen through the reaction mixture. The ozonide was stirred with dimethyl sulphide $(1 \mathrm{ml})$ for six hours, after which the solution was concentrated under reduced pressure and the residue was diluted with ether (50ml), washed with water, brine and dried over anhydrous sodium sulfate. Removal of the solvent afforded the dione $11(0.23 \mathrm{~g}, 93 \%)$ as a solid, mp $98^{0} \mathrm{C} ; v_{\max } / \mathrm{cm}^{-1} 2910$ and 1735; $\delta_{\mathrm{H}}(300 \mathrm{MHz})$ $1.22(3 \mathrm{H}, \mathrm{s}, \mathrm{Me}), 1.25(3 \mathrm{H}, \mathrm{s}, \mathrm{Me}), 1.70-2.30(7 \mathrm{H}, \mathrm{m}), 2.35\left(1 \mathrm{H}\right.$, br s, $\left.\mathrm{C}_{6} \mathrm{H}\right), 3.36(3 \mathrm{H}, \mathrm{s},-\mathrm{OMe})$ and 3.58-3.64 (1H, m, CH-OMe); $\delta_{\mathrm{C}}(75 \mathrm{MHz}) 10.4,10.7,19.1,25.6,48.0,51.3,51.5,55.1$, 56.2, 57.2, 75.4, 212.5 and 214.9; $\mathrm{m} / \mathrm{z} 222\left(\mathrm{M}^{+}\right.$19\%), 207 (3), 190 (5), 162 (35), 147 (31), 128 (100), 94 (95) and 71 (71); (Found: $\mathrm{M}^{+}, 222.1250 . \mathrm{C}_{13} \mathrm{H}_{18} \mathrm{O}_{3}$ requires 222.1246).

\section{Acknowledgements}

We thank the UGC, New Delhi for the award of a fellowship to K. K. and INSA, New Delhi for financial assistance (Senior Scientist to G. S. R. S. R).

\section{References}

1. Synthesis based on cyclohexadienes Part 37; for Part 36, see, Biju, P. J.; Pramod, K.; Subba Rao, G. S. R. ARKIVOC 2003, (iii), 88.

2. (a) Takemoto, T.; Nishimoto, N.; Nakai, S.; Takagi, N.; Hayashi, S.; Odashima, S.; Wada, Y.; Tetrahedron Lett. 1983, 24, 1057. (b) Nishimoto, N.; Nakai, S.; Takagi, N.; Hayashi, S.; Takemoto, T.; Odashima, S.; Kizu. H.; Wada, H. Phytochemistry 1984, 23, 139.

3. Nakai, S.; Takagi, N.; Miichi, H.; Hayashi, S.; Nishimoto, N.; Takemoto, T.; Kizu, H. Phytochemistry 1984, 23, 1703.

4. Monti, S. A.; Chen, S. C.; Yang, Y. L.; Yuan, S. S.; Bourgeosis, O. S. J. Org. Chem. 1978, 43, 4062.

5. Stork, G.; Baine. N. H. Tetrahedron Lett. 1985, 26, 5927. 
6. Stork, G.; Reynolds, M. E. J. Am. Chem. Soc. 1988, 110, 614.

7. Kaliappan, K.; Subba Rao, G.S.R. J. Chem. Soc., Perkin Trans.1 1997, 3393.

8. (a) Biju, P. J.; Subba Rao, G.S.R. Tetrahedron Lett. 1999, 40, 2405. (b) Biju, P. J.; Kaliappan, K.; Laxmish, M. S.; Subba Rao, G.S.R. J. Chem. Soc., Perkin Trans 12000 , 3714. 